\title{
On the viability of action research in education
}

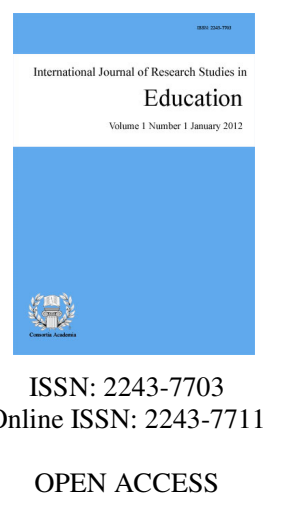

Shakouri, Nima $\bowtie<$

Roudbar Branch, Islamic Azad University, Iran (shakouri.ni@gmail.com)

\section{Abstract}

Knowledge is centered within society, and dynamism is based on the view that the world is constantly changing. In this regard, action research offers a tool for teachers to become the agents of change rather than as the recipients of knowledge. Furthermore, for the change to be consolidated, teachers should enter into dialogue with researchers. In fact, utterances of a single individual are barren until they are granted meaning by the other individuals. By elaborating on the tenets of action research, the paper is trying to confirm that the democratic nature of inquiry is per se well-appraised, but the applicability of action research in any context is under question. To the present writer, action research is not fulfilling these hopes because the teachers are not well-supported. However, besides investigating the philosophy adapted by action research, the writer suggests any attempt towards re-describing inquiry and abandoning the old terminologies inherited from traditional predecessors are worthwhile provided that the foundation of the so-called precondition, i.e., collaboration, for an action research is met.

Keywords: dialogue; action research; pragmatism; conscientization 


\section{On the viability of action research in education}

\section{Introduction}

The heated dialogues on the nature of knowledge have left us in an uneasy state. Whether this knowledge is the utterance of a single individual or a group of individuals has become the linchpin of our debate. Gergen (1994) focusing on the incapacity of the free standing signifier to bear meaning holds that a single word standing alone would signify nothing. Elsewhere, Gergen (2003) puts forth that even "the utterances of a single individual themselves possess no meaning" (p. 45). She also goes on to hold "they [utterances] stand barren until another affirms, or in effect, supplements these actions in such a way they are granted meaning” (p. 45). Coming to the realm of education, Glaserfeld (1995, cited in Williams \& Burdens, 1997) puts forth that knowledge does not belong to the teacher; the teacher cannot tell students what concepts to construct or how to construct them.

Accordingly, Philip (2000, cited in Hassaskhah, 2005) asserts knowledge is made not acquired. Henceforth, within a democratic context, individual minds are not respected as the center of meaning and action, but priority is given to the reality of relationship and democracy. In this way, action research originated from the philosophy of democracy is regarded as the vanguard of the movement. In this regard, Gergen (2003) declares that action research contributes to the achievement of democracy. At the heart of Gergen's optimistic beliefs, she claims by flowering of action research, we can develop 'vocabularies of practice' (p. 46). Not discarding the traditional values of freedom in talk, the paper is in an attempt to hold that the success of democratic practices does not depend on the structure of individual choices rather on relational choices. In a sense, Gergen holds "If all meaning finds its origins within relationship, then it is not the individual voice that is important to a viable society but the process of conjoint meaning making" (p. 46); nevertheless, these, regrettably, have become "less-than-realistic wishes" (Dornyei, 2007, p. 192). In effect, the conduction of action research entails expertise on the part of teachers and readiness of the context in which the type of research is going to be employed.

\section{Literature review}

\subsection{Definition}

Action research does not appear revolutionary (Huberman, 1996). Action research was first coined by Lewin (1940, cited in Burgess, 2006) to link the cycles of theory, practice, and problem-solving. The cyclical nature of action research, as Davis (2007) declares, implies that "action research is clearly not a linear research methodology nor can it be tightly designed in advance” (p 189). She continues that the concept of "change does not just happen at the end [;] it is embedded in the research process, happening throughout” (p. 189). Along the same line, Kemmis and McTaggart (1982) define action research as "trying out ideas in practice as a means of improvement and as a means of increasing knowledge about the curriculum, teaching, and learning” (p. 5). Similarly, Reason and Bradbury (2001) refer to action research as "a democratic process concerned with developing practical knowing in the pursuit of worthwhile human purposes, grounded in a participatory worldview" (p. 1). Reason and Bradbury also continue that action research "seeks to bring together action and reflection, theory, and practice, in participation with others, in the pursuit of practical solutions to issues of pressing concern to people” (p. 1).

Accordingly, Wallace (1991, cited in Nunan, 2001) maintains that action research can be attractive for two reasons: it can have a specific and immediate outcome which can be directly related to practice in the teacher's own context, and also the findings of such research might be primarily specific; that is, it is not claimed that they are necessarily of general application, and therefore the methods might be more free-ranging than those of 
conversational research.

\subsection{The Stance of dialogue in action research}

Claiming that action research is in attempt to connect word to world is undeniable. To connect word to world, it is indispensable to bridge the gap between practice and theory. What brings these dualist terms, i.e. theory and practice, together is the concept of dialogic democracy rather than liberal democracy. Dialogic democracy, in contrast with liberal democracy, refers to "ordered [relationships] through dialogue rather than through embedded power" (Gergen, 2003, p. 53). To Giddens (1992), through dialogue, personal relationship develops and active trust is mobilized. It is a truism that through dialogues a form of rapport is expected between the teacher and students, each of whom interprets the intention of the others. Through the process of interaction in a dialogue an activity is shaped which grounds the basis for students to liberate their potential.

To Prabhu (1987), the rapport represents a form of empathetic understanding of each other's behavior and is probably more productive of learning than any teaching procedure by itself can be. In fact, what language teaching professionalism seeks for is the way that perceptions can be shared through dialogue. Moreover, as Prabhu asserts, without dialogue, teachers are forced towards routinization in teaching such that the classroom can easily cease to be a source of interpretable experience. Furthermore, participation in a dialogue can activate intuitions and help individuals develop a sense of plausibility capable of guiding as well as drawing on classroom experience.

\subsection{Reflective teaching and action research}

An important concept that makes action research distinct from traditional research is the notion of reflective practice (Nunan, 2001). Wallace (1991, cited in Nunan, 2001) holds research of this kind is simply an extension of the normal reflective practice of many teachers. Reflective practice means that you can never be sure that ideas have been fully explored and developed (Hillier, 2005). In fact, action research makes an endeavor to provide a link between theory and practice. The link between theory and practice, therefore, means that theory is grounded in practice, and the latter is not some kind of "thoughtless behavior which exists separately from theory” (Carr \& Kemmis, 1986, cited in Hilier, 2005, p. 10).

Wallace (1991, cited in Nunan, 2001) argues that reflective teaching provides a way of developing professional competence by integrating two sources of knowledge, received knowledge and experiential knowledge with practice. Along the same vein, Hillier (2005) puts forth, "by focusing on knowledge that is practically derived from solving problems, the gap between theory and practice is bridged" (p. 10). To Usher and Bryant (1989, cited in Hillier, 2005, pp. 10-11), this knowledge is situational in that it is "socially located, very often complex and problematic and consciously and intentionally carried out" (p. 10). In effect, for the knowledge to be reflectively analyzed, a range of qualities are needed: open-mindedness, active concern with aims and consequences of teaching, ability to employ methods of enquiry, ability to employ self-reflection and ability to engage in a dialogue (Pollard, 1997).

Burton (2009) also referring to Schön's (1983) distinction between reflection-in-action and reflection-on-action states that Schön's (1983) distinction is a reminder that teachers are constantly making decisions in the classroom. Nevertheless, to Schön, teachers' decisions have to be based on knowledge and previous experience of some kind. In sum, to Schön drawing on knowledge and previous experience will contribute to teachers' theorizing that is manifested in two ways: "drawing upon theories in use when reflecting in action, and drawing upon teaching experience and espoused theories when reflecting on action” (Burton, 2009, p. 299).

\subsection{Philosophy of action research}

The stance of action research in curriculum development has a rich history that can be traced back to praxis 
Shakouri, N.

as described by Freire (1970). Praxis involves a give-and-take relationship between theory and practice-between theorizing practice and practicing theory (Monchinski, 2008). As Freir (1985, cited in Monchinski, 2008) warns "cut-off from practice theory becomes a simple verbalism and separated from theory is nothing but blind activism” (pp. 1-2).

Along the same line with Freire's praxis, a relatively recent achievement in adult education theory is articulated by Mezirow's (1990) transformative learning theory. As to Levin and Martin (2007) "the triggering event for transformative learning is described as a 'disorienting dilemma'” (pp. 226-227). In fact, as Levin and Martin contend "something occurs that jars our habitual understanding of the world and we must develop a new understanding" (p. 226). It is necessary to remember that the root of transformative learning lies in the process of conscientization coined by Freire (1970). Along the same line, Levin and Martin continue that conscientization is a transformation that challenges habitual thinking and roles and enlightens the learners involved in the research project. Similarly, in Giroux's (1988) terminology, teachers are transformative intellectuals who have the knowledge and skill to critique and transform existing inequalities in society.

Nevertheless, several scholars (e.g., Rorty, 1999) assert the seeds of action research are to be found as early as the late $19^{\text {th }}$ century. It grew out of the moves by anti-Platonist educators including Dewey (1933) who in the early of the $20^{\text {th }}$ century was in challenge with the orthodoxy of the scientific research methods current in the field of education. Dewey's pragmatist philosophy was essentially democratic in nature, based on the ideas that researchers, practitioners, and others involved in the educational community should address their efforts toward educational inquiry collectively in order to confront common educational problems. In fact, in pragmatist philosophy, truth cannot be discovered; it must be realized in practice.

As Apple and Teitelbaum (2001) assert in Dewey's pragmatist philosophy, "social experimentation, rather than absolute principles, was needed to assess the worth of an idea or practice" (p. 196). Apple and Teirelbaum, furthermore, put forth that "this experimentation was to be guided not by random trial and error, however, but rather by scientific habits of mind" (p. 196). In fact, though in disfavor with such dualisms, i.e., practice and theory, Dewey (1933) was never in an attempt to find a compromise but rather to reconstruct the debate so that they were no longer viewed as opposites. Accordingly, Reason (2003) asserts that "the characteristic idea of philosophical pragmatism is that ideas and practices should be judged in terms of their usefulness, workability and practicality and that these are the criteria of their truth, rightness and value" (p.104).

\section{Re-describing inquiry in education}

Action research is an attempt to re-describe inquiry (Rorty, 1999). Reason (2003), in an interview with Richard Rorty who tracks his pragmatism to Dewey (1933), argues that just as Rorty who is re-describing philosophy, so action researchers are re-describing inquiry. Re-describing, according to Rorty (1989), refers to "a talent for speaking differently, rather than for arguing well as the chief instrument for cultural change" (cited in Reason, 2003, p. 105). That is, we are attempting to speak differently in the face of an entrenched vocabulary. As Reason and Bradbury (2001) maintain, action research must not be seen as simply another methodology in the toolkit of disinterested social science; action research is an orientation to inquiry rather than a methodology. It has different purposes, is based on different relationships, and has different ways of conceiving knowledge and its relation to practice. In fact, as to Rorty (1999), the goal of inquiry is not seeking for truth. In fact, the purpose of inquiry is to achieve agreement among human beings about what to do in order to achieve the goals. Hence, the importance is placed on developing a talent for speaking differently and articulating what we do with new metaphors rather than being caught in entrenched vocabularies. In other words, on claiming that re-describing is an important term for Rorty, Reason (1989) continues that in order to argue cogently for a recently born phenomenon, we never rest our claim on the theorem that "our view is a better representation of reality; we are caught in a contest between an entrenched vocabulary which has become a nuisance and a half-formed vocabulary which vaguely promises great things" (p. 9). Rorty (1999) argues that we need to "slough off a lot of intellectual baggage which we inherited from the Platonic tradition" (p. 13). According to Reason (2003), Rorty 
On the viability of action research in education

(1999) even resists the use of the term relativist to describe himself and other pragmatists. In this regard, Rorty puts forth:

I think it is important that we who are accused of relativism stop using the distinctions between finding and making, discovery and invention, objective and subjective. We should not let ourselves be called subjectivists .... We must repudiate the vocabulary our opponents use, and not let them impose it on us. (p. 18)

In sum, repudiating the vocabulary employed by our opponents or re-describing new terminologies in education entails casting doubt. In fact, “doubts about the validity of one's convictions breeds relativism” (Hiley, 2007, p. 102). Goldfarb (1991, cited in Hiley, 2007) similarly puts forth, "cynicism has its philosophical basis in relativism. When we no longer know that our way of life is the best way, we learn to respect others, but we also begin to doubt ourselves” (p. 24). In this line, educators, curriculum developers, and teachers are constantly testing theories against a hard reality, until a new paradigm emanates. In fact, an old paradigm never shifts if it is fully consistent with reality, and if it is wrong, it is apt to shift since reality eventually proves inconsistent with it. In a nutshell, the purpose of inquiry in action research is to let individuals have an ear to different views and tolerating opposing ideas, we come to agreement. However, supporting mindless conformity, as Chernus (1992) declares, can put an end to diversity. Chernus further adds that if we impose our experience on others in order to achieve conformity, we certainly close our eyes to many new experiences and become narrow-minded. .

\section{Qualitative nature of action research}

The philosophical shift from social facts as objective to subjective contributes to the epistemology of qualitative research — to the ideas that knowledge is socially constructed rather than delineated a priori. For knowledge to be socially constructed, qualitative research, in general, and action research, in particular, require a community setting, the key element of which is negotiation (Wilson, 1980). In a sense, through the process of negotiation, conformity is built up. In other words, through the process of negotiation, agreement on the probable issues is reached; henceforth, this conformity will be conducive to the emergence of a change in education. Thus, as Cavagnini (2012) claims, getting distant from conformity and confining oneself to a fixed, predetermined category leads to intellectual, cultural, and personal stagnation.

No one denies the fact that improving education entails changing people-their beliefs, ideas, and their relationship. Change seems to be an undisputable constant in education. Education as the most contested sector in any country involves change, but, as Myers (2000) contends, the change does not transpire recklessly. Both Platonist and anti-Platonist perspectives in education have undergone plausible changes. There are a variety of factors that traces the change, but what is undeniable is that power and politics often dictate which path in education will hold sway at any point in time in any part of the world. In effect, research, per se, pursues a top-down pedagogy, and action research is not an exception. Nevertheless, as a practical approach to professional inquiry, action research can be conducive to change in teachers' beliefs system. This type of research also helps teachers control their professional situation (Waters-Adams, 2006). In brief, as to Elliot (1981), action research aims at promoting a teacher's practical wisdom.

The implications derived from action research are highly institutionally oriented rather than emergent (Newton \& Burgess, 2008). Thus, the findings of action research in education are more or less incommensurable since the research is context specific and is controlled by teachers' sense of plausibility that is highly subjective and less generalizable. Nevertheless, Newton and Burgess (2008) maintain "even if practitioner action research represents a new paradigm, it is commensurable with qualitative research” (p. 22). Action research, as a qualitative orientation to inquiry, is largely impossible to escape from subjective experience. Besides, in action research, studies are often difficult to replicate as this research involves the accumulation of local knowledge (Bradbury-Huang, 2010).

"Action research is now ready to attain the level of a mature research approach within a qualitative 
Shakouri, N.

research paradigm" (Newton \& Burgess, 2008, p. 27). In a sense, the success of this method in a qualitative paradigm as Nielson (2005) declares, rests upon its high demands (1) to handle the growing complexity and insecurity present in modern societies, (2) to develop democratic dialogue about the development of organizations, enterprises and communities, and (3) to produce knowledge and change co-operatively. Furthermore, on the plausibility of action research in education, Popplewell and Hayman (2012) outline that action research (1) is more participatory, (2) creates space for learning and reflexivity, (3) is less extractive, (4) supports downward accountability, and (5) can cope with complexity.

In sum, in action research, words rather than numbers are the common currency of dialogue. Therefore, action research tends to be qualitative. However, action research can be quantitative, too. A quantitative action research often entails marginalizing anything that we can't easily attach numbers to. Still, usually, the tool of action research to exert change is language rather than numbers; in fact, it is the use of natural language that is conducive to the emergence of a paradigm that is participative and responsive to the situation.

\section{Problematic issues in action research}

One big problem with action research in educational context is that there is too little of it (Dornyei, 2007). What we frequently have in published studies of action research is the revitalization of the tenets of critical pedagogy. But little has been reported on the viability of providing relationship between practice and theory. How is it plausible for a novice teacher in an unsupportive teaching climate to play the role of researcher? Furthermore, what tangible strategies do we offer in order to establish the rapport between practice and theory? The ideology behind action research is undeniably well appreciated, but it seems not viable for any context.

That Dewey's (1933) pragmatist philosophy is a revolution in education is not dubious. Still, the viability of pragmatist philosophy in any context is not more than an ideological wish. That is, whether the dialogic democracy that Dewey sees it as a platform that liberal democracy can be achieved is applicable in any context is dubious. In this regard, Apple and Teirelbaum (2001) claim "it is questionable whether the kind of common social purpose and active citizenry that Dewey advocated is possible in a capitalist society of such striking inequities of power and wealth and the dominance of consumerism” (p. 197).

Arguably, the most common objections to action research have concerned what Kvale (1994, cited in Krastel \& Lacorte, 2005, p.45) calls "the holy trinity of scientific investigation: validity, generalizability, and reliability". Does action research measure what it purports to measure; is it internally valid? How accurate are the findings, and do they apply to other similar context; is it externally generalizable? Do similar action research projects have similar findings? is it reliable? In any case as, Nunan (1992) claims, a major limitation of action research is concerned with the validity and reliability of action research in foreign language context. Although due to dynamic nature of action research, reliability may become a less common concern (Ellis, 1989), teachers should be motivated to disseminate their findings through professional meetings and publications to illuminate the issue for other classroom teachers who may find themselves in similar situations (Lincoln \& Guba, 1985).

Although several scholars (e.g., Ellis, 1989; Lincoln \& Guba, 1985) argue that since the mission of action research is to interpret phenomena rather than to explain their causes, it is not felt important to be concerned with such issues as reliability and validity. Nevertheless, Krastel and Lacorte (2005) assert that "in informing both educational practice and theory, such a discussion of validity and reliability is necessary to acknowledge the empirical soundness of action-based research" (p. 45).

Although no one denies that considering teachers as passive recipients of researcher knowledge has not been successful in the past, trying to get teachers to generate their own knowledge and theories is not justified. As Dornyei (2007) puts forth, "the danger is that even if teachers decide to initiate an action research project, the chances are that with little background knowledge and insufficient research expertise they will produce questionable or trivial results" (p. 192). Moreover, without a clear understanding of the research process, the teachers waste their time and energy. In effect, for a teacher's action to be informed by reflection, we need to 
take phronesis into consideration. Hillier (2005), in defining phrones, asserts that it means "practical knowledge that is defined as rightness for action" (p. 16). In fact, it is necessary for teachers to know that their practice is prudent. The teachers are requested to possess phronesis which is "the most supreme intellectual virtue and an indispensable feature of practice” (Carr, 1986, cited in Hillier, 2005 p.16). As Carr insists, the person who lacks phronesis may be technically accountable but never morally answerable. Thus, in disfavor with the culture of modernity, action research: makes an endeavor to prioritize the concepts of phronesis and praxis that have been rendered marginal in modernity. Thus, as to Carr (2006), action research is

\section{Nothing other than a post-modern manifestation of the pre-modern Aristotelian tradition of practical philosophy. As such, it would be a mode of inquiry whose chief task was to reclaim the sphere of praxis from its modern assimilation to the sphere of techne by fostering the kind of dialogical communities in which open conversation can be protected from the domination of a research methodology. This is not an easy task to achieve. (pp. 433-434)}

Ironically, action research has been to democratize research (Dornyei 2007); that is, to avoid a top-down pedagogy in conducting research. Nevertheless, the movement according to Dornyei is top-down per se as the researcher tries to promote it. In line with Dornyei (2007), Bartles (2002), also, outlines at least three reasons for action research not becoming prominent. Namely, the teachers lack the time, the incentives, and the expertise or professional support to get meaningfully engaged with research. Henceforth, it would be unrealistic to expect that the teachers can conduct action research and develop materials when they feel lacking expertise and experience. In this regard, the teachers who live in their espoused beliefs employ their theory as filters and never let other voices be heard. Along the same line, Hopkins (1993) contends that action research has the potential to "trap teachers within a framework which they might come to depend on and which will, consequently, inhibit independent action” (p. 55).

\section{Conclusion}

The paper has provided a detailed consideration of the nature of action research. However, concerns about the research rudiments were voiced. No one denies that action research pursues a precious mission. Nevertheless, to conduct an action research, the necessary tools and conditions including readiness on the part of teachers and context are supposed to be well prepared. Action research, as one way of enhancing professional confidence (Hopkins, 1993), appears to lie at the edge of ideality. Unless this ideality is materialized, there will be a glimmer of hope.

Action researchers have come a long way in learning how to develop mutuality in conversation. However, there is often little recognition of how it has to be developed. It is naïve to claim that collaboration happens straight away, although no one denies that our world neither consists of separate things, nor is it constructed through language, but rather emerges through relationships which we co-author and in which we partake. But what gazed us into wonder is that action research per se is personal; henceforth, it can produce severe tensions in the maintenance of a collaborative situation (Watters-Adams, 1994). Thus, how is the collaboration which is a precondition for conducting an action research going to be achieved when we engage teachers, curriculum developers ...whose values are different? Furthermore, considering action research as methodology or a 'strategic action' (Kemmis \& McTaggart, 1982) implies that it has no aim or what Watters-Adams (1994) claims, it cannot have an aim. It is, therefore, difficult to maintain rigor in data gathering. In a nutshell, if we consider collaboration as inevitability of action research, it can be guessed until this inevitability is not met, ideality gets far from reality.

\section{References}

Apple, M. W., \& Teirelbaum, K. (2001). John Dewey. In J. A. Palmer, L. Bresler, \& D. E. Cooper (Eds), Fifty major thinkers on education: From Confucius to Dewey (pp. 194-198). London: Routledge. 
Shakouri, N.

Bartles, N. (2002). Professional preparation and action research: Only for language teachers? TESOL Quarterly, 36(1), 71-79. http://dx.doi.org/10.2307/3588361

Bradbury-Huang, H. (2010). What is good Action Research? Why the resurgent interest? Action Research, 8(1), 93-109. http://dx.doi.org/10.1177/1476750310362435

Burgess, J. (2006). Participatory action research. Action Research, 4(4), 419-437. http://dx.doi.org/10.1177/1476750306070104

Burton, J. (2009). Reflective practice. In A. Burton \& J. C. Richards (Eds), The Cambridge guide to second language teacher pedagogy (pp. 298-308). Cambridge: Cambridge University Press.

Carr, W. (2006). Journal of philosophy of education. Journal of philosophy of education, 40(4), 421-435. http://dx.doi.org/10.1111/j.1467-9752.2006.00517.x

Cavagnini, K. (2012). Description of scientific revolutions: Rorty's failure at redescribing scientific progress. Stance, 5, 31-43.

Chernus, I. (1992). Fredric Jameson's interpretation of postmodernism. Retrieved October 15, 2013, from http://spot.colorado.edu/ chernus/NewspaperColumns/LongerEssays/JamesonPostmodernism.htm

Davis, J. M. (2007). Rethinking the architecture: An action researcher's resolution to writing and presenting their thesis. Action Research, 5(2), 181-198. http://dx.doi.org/10.1177/1476750307077322

Dewey, J. (1933). How we think: A restatement of the relation of reflective thinking to the education process. Boston: Heath.

Dornyei, Z. (2007). Research methods in applied linguistics. Oxford: Oxford University Press.

Elliott, J. (1981). Action research: a framework for self-evaluation in schools. TIQL working paper no.1. Cambridge: Cambridge Institute of Education.

Ellis, R. (1989). Researching classroom language learning. In C. Brumfit \& R. Mitchell (Eds.), Research in the language classroom (pp. 54-70). Southampton: Modern English Publications.

Freire, P. (1970). Pedagogy of the oppressed. New York: Continuum.

Gergen, K. J. (1994). Realities and relationships. Cambridge: Harvard University Press.

Gergen, K. J. (2003). Action research and orders of democracy. Action Research, 1(1), 39-56. http://dx.doi.org/10.1177/14767503030011004

Giddens, A. (1992). The transformation of intimacy: sexuality, love and eroticism in modern societies. Cambridge: Polity.

Giroux, H. (1988). Teachers as intellectuals: A critical pedagogy for practical learning. Westport, CT: Bergin \& Garvey.

Hassaskhah, J. (2005). Cooperative learning. Rasht: Guilan University Press.

Hiley, D. R. (2007). Doubt and the demands democratic citizenship. Cambridge: Cambridge University Press.

Hillier, Y. (2005). Reflective teaching in further and adult education. New York: Continuum.

Hopkins, D. (1993). A teacher's guide to classroom research. Buckingham: Open University Press.

Huberman, M. (1996). Moving mainstream: Taking a closer look at teacher research. Language Arts, 73(2), 124-140.

Kemmis, S., \& McTaggart, R. (1982). The action research planner. Victoria, Australia: Deakin University Press.

Krastel, T. C., \& Lacorte, M. (2005). Action research in the L2 classroom: Conflicts, quality and contributions to knowledge. Retrieved October 16, 2013, from http://www2.dickinson.edu/prorg/nectfl/reviewarticles/56-krastel.pdf

Levin, M., \& Martin, A. W. (2007). The praxis of educating action researchers: The possibilities and obstacles in higher education. Action Research, 5(3), 219-229. http://dx.doi.org/10.1177/1476750307081014

Lincoln, Y., \& Guba, E. (1985). Naturalistic inquiry. Beverly Hills, CA: Sage.

Mezirow, J. (1990). Fostering critical reflection in adulthood: A guide to transformative and emancipatory learning. San Francisco: Jossey Bass.

Monchinski, T. (2008). Critical pedagogy and the everyday classroom. London: Springer.

Myers, M. (2000). Qualitative research and the generalizability question: Standing firm with proteus. Retrieved October 15, 2013, from http://www.nova.edu/ssss/QR/QR4-3/myers.html

Newton, P., \& Burgess, D. (2008). Exploring types of educational action research: Implications for research 
validity. International Journal of Qualitative Methods, 7(4), 18-30.

Nielsen, K. A. (2005). Sustainability and democracy in food production: Bridging consumption, working life, and environmental management. Action Research, 3, 157-173.

Nunan, D. (1992). Research methods in language learning. Cambridge: Cambridge University Press.

Nunan, D. (2001). Action research in language education. In D. R. Hall \& A. Hewings (Eds), Innovation in English language teaching (pp. 197-207). London: Routledge.

Pollard, A. (1997). Reflective teaching in the primary school ( $3^{\text {rd }}$ ed). London: Cassell.

Poplewell, R., \& Hayman, R. (2012). Where, how, and why are action research approaches used by international development non-governmental organizations? Retrieved October 15, 2013, from http://www.intrac.org/data/files/resources/752/Briefing-Paper-32-Where-how-and-why-are-Action-Rese arch-approaches-used-by-international-development-non-governmental-organisations.pdf

Prabhu, N. S. (1987). Second language pedagogy. Oxford: Oxford University Press.

Reason, P. (2003). Pragmatist philosophy and action research: Readings and conversation with Richard Rorty. Action Research, 1(1), 103-123. http://dx.doi.org/10.1177/14767503030011007

Reason, P., \& Bradbury, H. (Eds.). (2001). Handbook of action research: Participative inquiry and practice. London: Sage Publications.

Rorty, R. (1999). Philosophy and social hope. London: Penguin Books.

Schön, D. A. (1983). The reflective practitioner: how professionals think in action. New York: Basic books.

Sedeghi, S., \& Ketab, S. (2009). From liberal ostrichism to transformative intellectual: An Alternative role for Iranian critical pedagogues. ELTED, 12, 52-60.

Stephen, K., \& McTaggart, R. (1988). The Action research planner. Melbourne: Deakin University Press.

Waters-Adams, S. (1994). Collaboration and action research: a cautionary tale. Educational Action Research, 2(2), 195-210. http://dx.doi.org/10.1080/0965079940020205

Waters-Adams, S. (2006). Action research in education. Retrieved October 15, 2013, from http://www.edu.plymouth.ac.uk/resined/actionresearch/arhome.htm

Williams, M., \& Burden, R. L. (1997). Psychology for language teacher: A social constructivist approach. Cambridge: Cambridge University Press.

Wilson, T. D. (2000). Recent trends in user studies: action research and qualitative methods. Information Research, 5(3). Retrieved October 15, 2013, from http://informationr.net/ir/5-3/paper76.html 
Shakouri, N. 